\title{
Tact Optimization Algorithm of LED Bulb Production Line Based on CE- PSO
}

\author{
Xiao-Mei HU1,a, Yue YU ${ }^{1, b},{ }^{*}$ Ming-Hang $\mathrm{LI}^{1, \mathrm{c}}$ and Yi-Ning JIANG ${ }^{1, \mathrm{~d}}$ \\ ${ }^{1}$ School of Mechatronic Engineering and Automation, Shanghai Key Laboratory of Intelligent \\ Manufacturing and Robotics, Shanghai University, Shanghai, China, 200072 \\ asufeimasohxm@163.com,byuyuelee@163.com,c985590174@qq.com,d1456602479@qq.com
}

Keywords: Tact, Production line, CE-PSO.

\begin{abstract}
With the wide use of automatic production line in manufacturing enterprises, it is very important to calculate the optimal production tact to make production lines achieve maximum productivity. A CE-PSO algorithm is applied to optimize the tact of the LED bulb production line in this paper. The main parameters and the related concepts of line balancing are defined, and the multiobjective optimization problem of production line balancing is studied. The CE-PSO based tact optimization steps of LED bulb production line are described. The experimental results show that the tact optimization algorithm of LED bulb production line based on CE-PSO is effective and it provides a reference for enterprises to reduce tact and improve production efficiency.
\end{abstract}

\section{Introduction}

With the progress and development of science and technology, manufacture has been evolved into a complex engineering system composed of many manufacturing elements instead of a simple process of individual behavior and the isolated machine[1]. Production line is an effective combination of man and machine, which has been widely used in the manufacturing industry. Along with the emergence of flexible manufacturing, agile manufacturing, JIT manufacturing, networked manufacturing and so on[2], manufacturing technology began to develop in the direction of systematic, flexible, reconfigurable, integrated, networked, intelligent and green regeneration. The transformation of manufacturing mode and the manufacturing technology also influences planning, design and operation of manufacturing system deeply.

LED bulb production line relates to many parts and complex production process. The basic task of the LED bulb production process optimization is to maximize the rationalization of the production process. So the production process should be reasonably organized in space and time not only to ensure the production process continuously and rhythmically, but also to improve the production efficiency constantly, shorten the production cycle, accelerate the capital turnover and reduce the cost. The tact optimization of the production line can adopt Particle Swarm Optimization (PSO) algorithm and the manual balance search algorithm and so on, but the results of the convergence degree from these algorithms are not high[3]. At present, the study to improve particle swarm algorithm is a lot, including the chaos PSO algorithm, genetic particle swarm hybrid algorithm, adaptive immune PSO algorithm and the bee evolutionary PSO algorithm, etc[4]. To some extent, these algorithms can improve the particle population diversity, but they cannot amend the whole particle population during the search process[5]. In order to improve the convergence degree, Catfish Effect (CE) based PSO algorithm is used for optimizing the tact of LED bulb production line in order to improve the convergence speed of the algorithm and get the representative of the whole feasible solution space.

\section{Tact Optimization of LED Bulb Production Line based on CE-PSO Coding of Step and Station in LED Bulb Production Line}

LED bulb production line consists of seven stations, and each station has a multiple operating steps. So, the coding of the basic step is adopted. The processing time of each workpiece I on each device $\mathrm{J}$ is shown in Table1.

Table 1 shows machining processes on each station for each workpiece. The machining time of 
each workpiece on each step is tagged in brackets. Among them, $\mathrm{X}$ in the brackets represents an adjustable time, which depends on operation parameters of each step. And the remaining figures in the brackets represent time in seconds. Each station consists of several steps with precedence relationship. The priority relation diagrams of the stations are shown in Figure 1,2 and 3. The rest of the four stations have similar priority relation diagrams.

\section{Definition of Fitness Function}

Under the conditions of 7 stations and fixed layout in LED bulb production line, the fitness function $f_{1}$ and the objective function $\min f_{1}$ are constructed to realize the comprehensive optimal goals of the tact $T T$ and smoothness index $S I$. The fitness function can be expressed as:

$$
f_{1}=b_{1} * T T+b_{2} * S I
$$

In the function, $b_{1}$ and $b_{2}$ is the weight value, $b_{1}+b_{2}=1$. And their specific values depend on the specific situation. For example, $b_{1}>b_{2}$ means the proportion of the tact is bigger than the smoothness index.

\section{Solution Strategy}

According to the objective function $\min f_{1}$, the solution process is divided into two parts:

1) The solution based on the tact: On the premise of meeting the constraint conditions, a set of division schemes $\left\{S_{k} \mid k=1,2,3, \ldots, \mathrm{m}\right\}$ of production elements $J=\{1,2,3, \ldots, n\}$ with smaller tact are solved;

2) The solution based on Smoothness index: On the basis of the step 1, calculate the value of the Smoothness index $S I$ of each division scheme and take the division scheme with the smallest fitness function value for the optimal scheme.

Table1. Workpiece machining processes and time on station equipment

\begin{tabular}{|l|l|l|l|l|l|l|l|}
\hline \multicolumn{1}{|c|}{ Step } & & & & & & \\
\hline 1 & $I_{1}$ & $I_{2}$ & $I_{3}$ & $I_{4}$ & $I_{5}$ & $I_{6}$ & $I_{7}$ \\
\hline 2 & $J_{1}(0.1)$ & $J_{1}(10)$ & $J_{1}(10)$ & $J_{1}(10)$ & $J_{1}(10)$ & $J_{1}(10)$ & $J_{1}(10)$ \\
\hline 3 & $J_{2}(\mathrm{X})$ & $J_{2}(10)$ & $J_{2}(10)$ & $J_{2}(10)$ & $J_{2}(10)$ & $J_{2}(10)$ & $J_{2}(10)$ \\
\hline 4 & $J_{3}(\mathrm{X})$ & $J_{3}(20)$ & $J_{3}(20)$ & $J_{3}(20)$ & $J_{3}(20)$ & $J_{3}(20)$ & $J_{3}(20)$ \\
\hline 5 & $J_{4}(0.15)$ & $J_{4}(10)$ & $J_{4}(10)$ & $J_{4}(10)$ & $J_{4}(10)$ & $J_{4}(10)$ & $J_{4}(10)$ \\
\hline 6 & $J_{5}(0.05)$ & $J_{5}(10)$ & $J_{5}(10)$ & $J_{5}(10)$ & $J_{5}(10)$ & $J_{5}(10)$ & $J_{5}(10)$ \\
\hline 7 & $J_{6}(\mathrm{X})$ & $J_{6}(10)$ & $J_{6}(10)$ & $J_{6}(10)$ & $J_{6}(10)$ & $J_{6}(10)$ & $J_{6}(10)$ \\
\hline 8 & $J_{7}(0.15)$ & $J_{7}(10)$ & $J_{7}(10)$ & $J_{7}(10)$ & $J_{7}(10)$ & $J_{7}(10)$ & $J_{7}(10)$ \\
\hline 9 & $J_{8}(0.5)$ & $J_{8}(10)$ & $J_{8}(10)$ & $J_{8}(10)$ & $J_{8}(10)$ & $J_{8}(10)$ & $J_{8}(10)$ \\
\hline 10 & $J_{9}(0.04)$ & $J_{9}(10)$ & $J_{9}(10)$ & $J_{9}(10)$ & $J_{9}(10)$ & $J_{9}(10)$ & $J_{9}(10)$ \\
\hline 11 & $J_{10}(0.1)$ & $J_{10}(10)$ & $J_{10}(10)$ & $J_{10}(10)$ & $J_{10}(10)$ & $J_{10}(10)$ & $J_{10}(10)$ \\
\hline 12 & $J_{11}(0.04)$ & $J_{11}(10)$ & $J_{11}(10)$ & $J_{11}(10)$ & $J_{11}(10)$ & $J_{11}(10)$ & $J_{11}(10)$ \\
\hline 13 & $J_{12}(\mathrm{X})$ & $J_{12}(10)$ & $J_{12}(10)$ & $J_{12}(10)$ & $J_{12}(10)$ & $J_{12}(10)$ & $J_{12}(10)$ \\
\hline 14 & $J_{13}(\mathrm{X})$ & $J_{13}(10)$ & $J_{13}(10)$ & - & $J_{13}(10)$ & $J_{13}(10)$ & $J_{13}(10)$ \\
\hline 15 & $J_{14}(0.05)$ & $J_{14}(10)$ & $J_{14}(10)$ & - & $J_{14}(10)$ & $J_{14}(10)$ & $J_{14}(0.05)$ \\
\hline 16 & $J_{15}(0.1)$ & $J_{15}(10)$ & $J_{15}(10)$ & - & $J_{15}(10)$ & $J_{15}(10)$ & $J_{15}(0.1)$ \\
\hline 17 & $J_{16}(0.1)$ & $J_{16}(10)$ & $J_{16}(10)$ & - & $J_{16}(10)$ & $J_{16}(10)$ & $J_{16}(0.1)$ \\
\hline 18 & $J_{17}(0.3)$ & $J_{17}(10)$ & $J_{17}(10)$ & - & $J_{17}(10)$ & $J_{17}(10)$ & $J_{17}(0.3)$ \\
\hline 19 & $J_{18}(0.04)$ & - & - & - & - & - & $J_{18}(0.04)$ \\
\hline
\end{tabular}




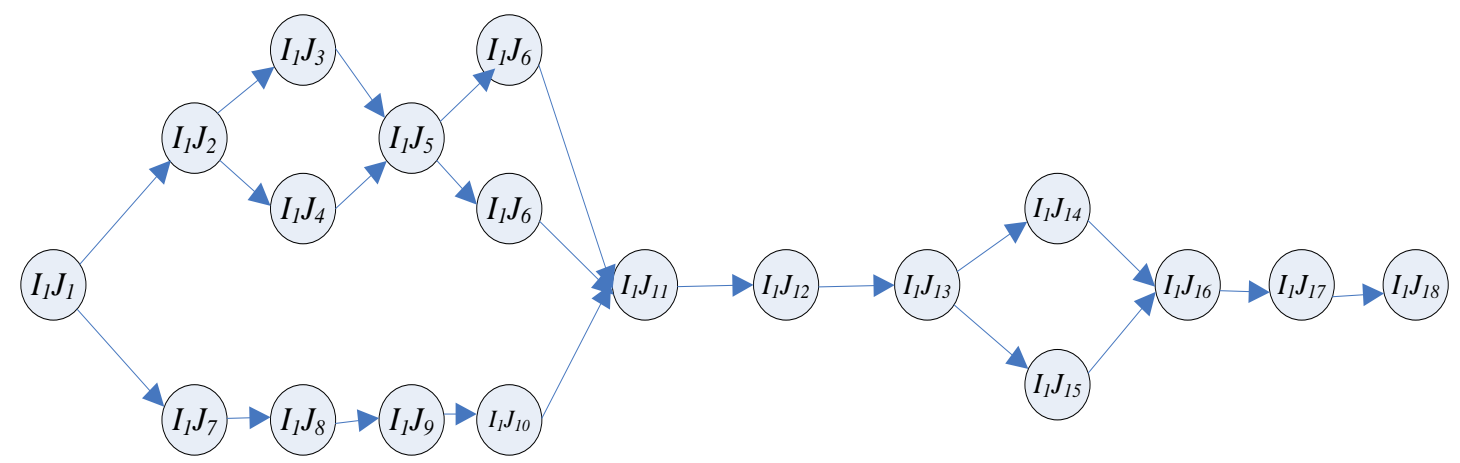

Figure 1. Priority relation diagram of the first station

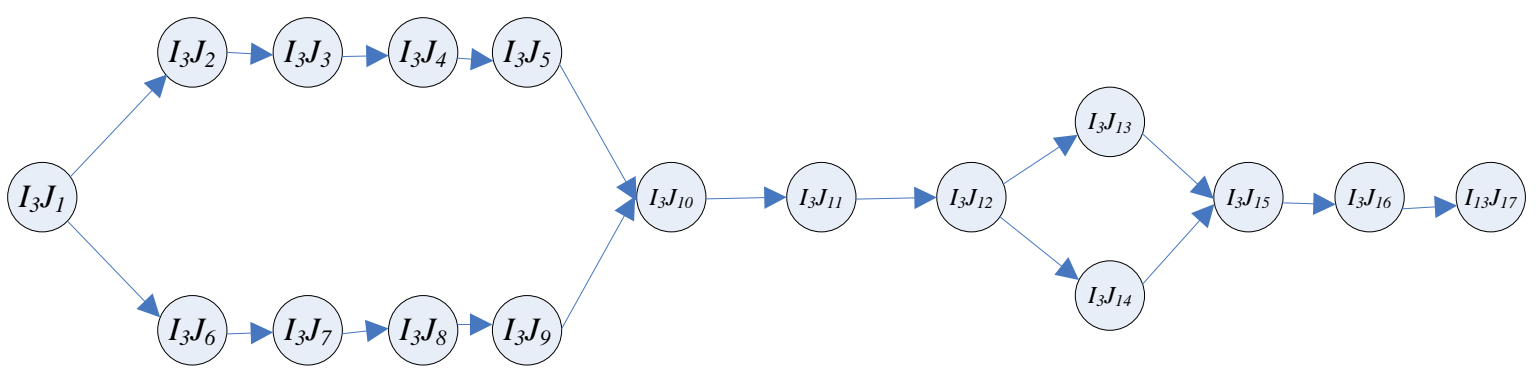

Figure 2. Priority relation diagram of the third station

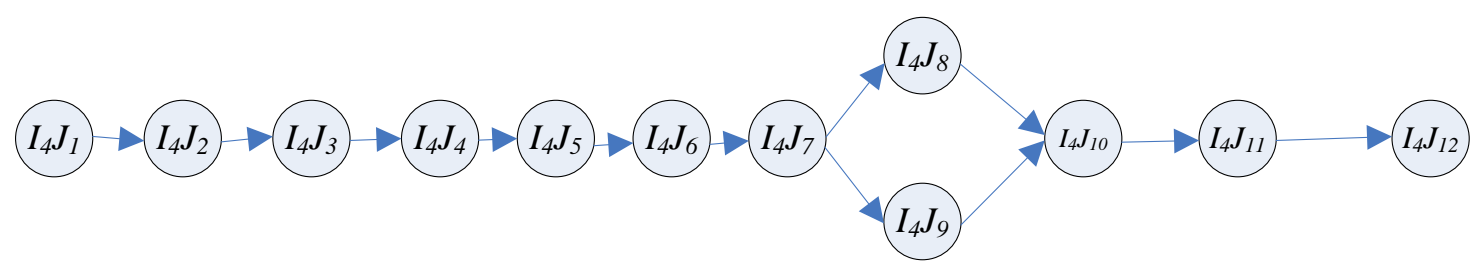

Figure 3. Priority relation diagram of the forth station

\section{Tact Optimization Steps of LED Bulb Production Line based on CE-PSO}

The steps of tack optimization of LED bulb production line based on CE-PSO are as follows:

(1) Algorithm initialization: Initialize the algorithm and set the initialization parameter: $\mathrm{w}=0.5$, $=0.5,=0.8 ;=0.5,=0.5$, determine the number of iterations $\mathrm{G}=400$, initialize generating $N$ Population;

(2) Initialization of the optimal tact particles $p B_{i}(t)$ of populations and global optimal tact particles $g B_{i}(t)$ : Take $N$ tact particles produced by algorithm initialization for the optimal tact particle of the population $p B_{i}(t)$, calculate the fitness value of each particle according to the fitness function $f_{1}$ and determine the global optimal tact particle $g B_{i}(t)$;

(3)During the iteration, a portion of the optimal tact particle $p B_{i}(t)$ of every subpopulation replace a portion of inferior tact particle of the present iteration population to make sure the diversity of the population;

(4)According to the particle update formula, calculate the tact $T T$ of population particles; Select the particles $X_{i}(t)$ with smaller tact $T T$ to calculate the smoothness index $S I$. According to fitness function $f_{1}$ to calculate the fitness value of each particle to determine the tact particles $p B_{i}(t)$ of this iteration population and the global optimal tact particles $g B_{i}(t)$;

(5) goto step (3) until $G$ iterations, output the optimal tact particles $g B_{i}(t)$. 


\section{The Simulation and Result Analysis}

\section{Software Operating Environment}

The configuration of computer is CPU Intel Core i7, CPU clock speed $2.60 \mathrm{GHz}$, internal storage 12.00 GB, and windows7 operating system. Matlab is used to achieve the CE-PSO algorithm.

\section{Operation Elements of LED Bulb Production Line}

The LED bulb production line consists of 7 stations and 112 steps. The whole production line owns 112 operation elements. According to real position and the constraint areaof the production line, the standard work time of the operation elements and the assemblyoperation elements of the LED bulb production line are shown as Table 2.

\section{The Result Analysis and Comparison}

CE-PSO algorithm is adopted to optimize tact and the optimization results are shown in Table 3. Specific conditions are as follows:

(1)Cylinder: The working air pressure: $0.1 \sim 0.8 \mathrm{Mpa}$; The working load: $0.5 \sim 3 \mathrm{Kg}$; The quantity of flow: 200 900 ml/s; The temperature: $0 \sim 50{ }^{\circ} \mathrm{C}$;

(2)Working frequency of stepping motor: $30 \sim 60 \mathrm{~Hz}$;

(3)Working frequency of transformer: $40 \sim 80 \mathrm{~Hz}$.

From table 3, optimization time of loading lamp cup in station 1 is $6.93 \mathrm{~s}$, optimization time of Installing the radiator in station 2 is $6.74 \mathrm{~s}$ and $7.75 \mathrm{~s}$ for installing light edition pack light in station 3 , 6.64s for locking screw in station 4, 6.76s for detecting current in station 5, 6.95s for installing lamp shade in station $6,6.88 \mathrm{~s}$ for light bulb blanking in step 7. Based on the analysis above, the tact time of the whole LED bulb production line is $6.95 \mathrm{~s}$.

PSO algorithm and manual balance search algorithm are also used to optimize tact of LED bulb production line, and the optimization results are compared in Figure 4. From Figure 4,

Table 2. Assembly operation elements with work time in LED bulb production line

\begin{tabular}{|l|l|l|l|l|l|}
\hline $\begin{array}{l}\text { operation step } \\
\text { elements }\end{array}$ & $\begin{array}{l}\text { Work } \\
\text { step label }\end{array}$ & $\begin{array}{l}\text { work } \\
\text { time(s) }\end{array}$ & $\begin{array}{l}\text { operation step } \\
\text { elements }\end{array}$ & $\begin{array}{l}\text { Work } \\
\text { step label }\end{array}$ & $\begin{array}{l}\text { work } \\
\text { time(s) }\end{array}$ \\
\hline Buffer downward & $I_{1} J_{1}$ & 0.13 & Cylinders right line & $I_{1} J_{2}$ & 2.32 \\
\hline Cylinder downward & $I_{1} J_{3}$ & 0.44 & Grip flip & $I_{1} J_{4}$ & 0.15 \\
\hline Grip grab lamp cup & $I_{1} J_{5}$ & 0.05 & Cylinder upward & $I_{1} J_{6}$ & 0.44 \\
\hline Grip flip & $I_{1} J_{7}$ & 0.15 & $\begin{array}{l}\text { Times the speed chain } \\
\text { transmission }\end{array}$ & $I_{1} J_{8}$ & 0.43 \\
\hline Sensors in place & $I_{1} J_{9}$ & 0.04 & $\begin{array}{l}\text { Jack lifting cylinder } \\
\text { upward }\end{array}$ & $I_{1} J_{10}$ & 0.12 \\
\hline Sensors in place & $I_{1} J_{11}$ & 0.04 & Cylinders left line & $I_{1} J_{12}$ & 2.78 \\
\hline Cylinder downward & $I_{1} J_{13}$ & 0.54 & Grip loosened & $I_{1} J_{14}$ & 0.11 \\
\hline Stop the downward & $I_{1} J_{15}$ & 0.13 & Jack-up downward & $I_{1} J_{16}$ & 0.12 \\
\hline Times the speed chain & $I_{1} J_{17}$ & 0.32 & Sensors in place & $I_{1} J_{18}$ & 0.04 \\
\hline $\begin{array}{l}\text { Block upward, buffer } \\
\text { downward }\end{array}$ & $I_{1} J_{19}$ & 0.13 & Buffer downward & $I_{2} J_{1}$ & 0.13 \\
\hline Cylinder right & $I_{2} J_{2}$ & 1.43 & Cylinder downward & $I_{2} J_{3}$ & 0.21 \\
\hline $\begin{array}{l}\text { Chuck absorb light } \\
\text { radiator }\end{array}$ & $I_{2} J_{4}$ & 0.21 & Cylinder upward & $I_{2} J_{5}$ & 0.34 \\
\hline $\begin{array}{l}\text { Times the speed chain } \\
\text { transmission }\end{array}$ & $I_{2} J_{6}$ & 0.32 & Sensors in place & $I_{2} J_{7}$ & 0.04 \\
\hline Top of the upside & $I_{2} J_{8}$ & 0.12 & Sensors in place & $I_{2} J_{9}$ & 0.04 \\
\hline Cylinder line left & $I_{2} J_{10}$ & 1.54 & Cylinder downward & $I_{2} J_{11}$ & 0.38 \\
\hline $\begin{array}{l}\text { Sucker blow, place the } \\
\text { radiator }\end{array}$ & $I_{2} J_{12}$ & 0.21 & Stop the downward & $I_{2} J_{13}$ & 0.13 \\
\hline
\end{tabular}


Table2. Assembly operation elements with work time in LED bulb production line

\begin{tabular}{|c|c|c|c|c|c|}
\hline $\begin{array}{l}\text { operation step } \\
\text { elements }\end{array}$ & $\begin{array}{l}\text { Work } \\
\text { step label }\end{array}$ & $\begin{array}{l}\text { work } \\
\text { time(s) }\end{array}$ & $\begin{array}{l}\text { operation step } \\
\text { elements }\end{array}$ & $\begin{array}{l}\text { Work } \\
\text { step label }\end{array}$ & $\begin{array}{l}\text { work } \\
\text { time(s) }\end{array}$ \\
\hline Jack-up downward & $I_{2} J_{14}$ & 0.12 & $\begin{array}{l}\text { Times the speed chain } \\
\text { transmission }\end{array}$ & $I_{2} J_{15}$ & 0.3 \\
\hline Sensors in place & $I_{2} J_{16}$ & 0.04 & $\begin{array}{l}\text { Block upward, buffer } \\
\text { downward }\end{array}$ & $I_{2} J_{17}$ & 0.13 \\
\hline Buffer downward & $I_{3} J_{1}$ & 0.13 & Cylinder right & $I_{3} J_{2}$ & 1.41 \\
\hline Cylinder downward & $I_{3} J_{3}$ & 0.23 & $\begin{array}{l}\text { Chuck absorb light } \\
\text { board }\end{array}$ & $I_{3} J_{4}$ & 0.21 \\
\hline Cylinder upward & $I_{3} J_{5}$ & 0.34 & $\begin{array}{l}\text { Times the speed chain } \\
\text { transmission }\end{array}$ & $I_{3} J_{6}$ & 0.32 \\
\hline Sensors in place & $I_{3} J_{7}$ & 0.04 & Top of the upside & $I_{3} J_{8}$ & 0.12 \\
\hline Sensors in place & $I_{3} J_{9}$ & 0.04 & Cylinder on the left & $I_{3} J_{10}$ & 1.54 \\
\hline Cylinder downward & $I_{3} J_{11}$ & 0.38 & $\begin{array}{l}\text { Sucker blow, place the } \\
\text { light source }\end{array}$ & $I_{3} J_{12}$ & 0.21 \\
\hline Stop the downward & $I_{3} J_{13}$ & 0.13 & Jack-up downward & $I_{3} J_{14}$ & 0.12 \\
\hline $\begin{array}{l}\text { Times the speed chain } \\
\text { transmission }\end{array}$ & $I_{3} J_{15}$ & 0.3 & Sensors in place & $I_{3} J_{16}$ & 0.04 \\
\hline $\begin{array}{l}\text { Block upward, buffer } \\
\text { downward }\end{array}$ & $I_{3} J_{17}$ & 0.13 & Buffer downward & $I_{4} J_{l}$ & 0.13 \\
\hline $\begin{array}{l}\text { Times the speed chain } \\
\text { transmission }\end{array}$ & $I_{4} J_{2}$ & 0.24 & Sensors in place & $I_{4} J_{3}$ & 0.04 \\
\hline Top of the upside & $I_{4} J_{4}$ & 0.12 & Sensors in place & $I_{4} J_{5}$ & 0.04 \\
\hline Cylinder downward & $I_{4} J_{6}$ & 0.45 & $\begin{array}{l}\text { Lock screw mounting } \\
\text { screw down the screws }\end{array}$ & $I_{4} J_{7}$ & 2.78 \\
\hline Stop the downward & $I_{4} J_{8}$ & 0.13 & Jack-up downward & $I_{4} J_{9}$ & 0.12 \\
\hline $\begin{array}{l}\text { Times the speed chain } \\
\text { transmission }\end{array}$ & $I_{4} J_{10}$ & 0.34 & Sensors in place & $I_{4} J_{11}$ & 0.04 \\
\hline $\begin{array}{l}\text { Block upward, buffer } \\
\text { downward }\end{array}$ & $I_{4} J_{12}$ & 0.13 & Buffer downward & $I_{5} J_{1}$ & 0.13 \\
\hline $\begin{array}{l}\text { Times the speed chain } \\
\text { transmission }\end{array}$ & $I_{5} J_{2}$ & 0.23 & Sensors in place & $I_{5} J_{3}$ & 0.04 \\
\hline Top of the upside & $I_{5} J_{4}$ & 0.12 & Sensors in place & $I_{5} J_{5}$ & 0.04 \\
\hline $\begin{array}{l}\text { Electric performance } \\
\text { test bulb }\end{array}$ & $I_{5} J_{6}$ & 3.5 & $\begin{array}{l}\text { Times the speed chain } \\
\text { transmission }\end{array}$ & $I_{5} J_{7}$ & 0.32 \\
\hline Sensors in place & $I_{5} J_{8}$ & 0.04 & $\begin{array}{l}\text { Block upward, buffer } \\
\text { downward }\end{array}$ & $I_{5} J_{9}$ & 0.13 \\
\hline Cylinder downward & $I_{5} \mathrm{~J}_{10}$ & 0.21 & Grip grab & $I_{5} J_{11}$ & 0.13 \\
\hline Cylinder upward & $I 5 J_{12}$ & 0.15 & Stop the downward & $I_{5} J_{13}$ & 0.13 \\
\hline Jack-up downward & $I_{5} J_{14}$ & 0.12 & $\begin{array}{l}\text { Times the speed chain } \\
\text { transmission }\end{array}$ & $I_{5} J_{15}$ & 0.34 \\
\hline Sensors in place & $I_{5} J_{16}$ & 0.04 & $\begin{array}{l}\text { Block upward, buffer } \\
\text { downward }\end{array}$ & $I_{5} J_{17}$ & 0.13 \\
\hline Buffer downward & $I_{6} J_{1}$ & 0.13 & Cylinder right & $I_{6} J_{2}$ & 1.67 \\
\hline $\begin{array}{l}\text { Electric cylinder } \\
\text { downward }\end{array}$ & $I_{6} J_{3}$ & 0.82 & Chuck learned chimney & $I_{6} J_{4}$ & 0.23 \\
\hline $\begin{array}{l}\text { Electric cylinder } \\
\text { upward }\end{array}$ & $I_{6} J_{5}$ & 0.67 & $\begin{array}{l}\text { Times the speed chain } \\
\text { transmission }\end{array}$ & $I_{6} J_{6}$ & 0.32 \\
\hline Sensors in place & $I_{6} J_{7}$ & 0.04 & Top of the upside & $I_{6} J_{8}$ & 0.12 \\
\hline
\end{tabular}


Table2. Assembly operation elements with work time in LED bulb production line

\begin{tabular}{|l|l|l|l|l|l|}
\hline $\begin{array}{l}\text { operation step } \\
\text { elements }\end{array}$ & $\begin{array}{l}\text { Work } \\
\text { step label }\end{array}$ & $\begin{array}{l}\text { work } \\
\text { time(s) }\end{array}$ & $\begin{array}{l}\text { operation step } \\
\text { elements }\end{array}$ & $\begin{array}{l}\text { Work } \\
\text { step label }\end{array}$ & $\begin{array}{l}\text { work } \\
\text { time(s) }\end{array}$ \\
\hline Sensors in place & $I_{6} J_{9}$ & 0.04 & Cylinder on the left & $I_{6} J_{10}$ & 2.12 \\
\hline $\begin{array}{l}\text { Electric cylinder } \\
\text { downward }\end{array}$ & $I_{6} J_{11}$ & 1.07 & $\begin{array}{l}\text { Sucker blow, install the } \\
\text { lamp shade }\end{array}$ & $I_{6} J_{12}$ & 0.31 \\
\hline Stop the downward & $I_{6} J_{13}$ & 0.13 & Jack-up downward & $I_{6} J_{14}$ & 0.12 \\
\hline $\begin{array}{l}\text { Times the speed chain } \\
\text { transmission }\end{array}$ & $I_{6} J_{15}$ & 0.23 & Sensors in place & $I_{6} J_{16}$ & 0.04 \\
\hline $\begin{array}{l}\text { Block upward, buffer } \\
\text { downward }\end{array}$ & $I_{6} J_{17}$ & 0.13 & Buffer downward & $I_{7} J_{1}$ & 0.13 \\
\hline $\begin{array}{l}\text { Times the speed chain } \\
\text { transmission }\end{array}$ & $I_{7} J_{2}$ & 0.43 & Sensors in place & $I_{7} J_{3}$ & 0.04 \\
\hline Top of the upside & $I_{7} J_{4}$ & 0.12 & Sensors in place & $I_{7} J_{5}$ & 0.04 \\
\hline $\begin{array}{l}\text { Cylinder downward } \\
I_{7} J_{6}\end{array}$ & 0.43 & $\begin{array}{l}\text { Gripper grab the light } \\
\text { bulb }\end{array}$ & $I_{7} J_{7}$ & 0.12 \\
\hline Cylinder upward & $I_{7} J_{8}$ & 0.32 & Stop the downward & $I_{7} J_{9}$ & 0.13 \\
\hline Jack-up downward & $I_{7} J_{10}$ & 0.12 & $\begin{array}{l}\text { Times the speed chain } \\
\text { transmission }\end{array}$ & $I_{7} J_{11}$ & 0.43 \\
\hline Sensors in place & $I_{7} J_{12}$ & 0.04 & $\begin{array}{l}\text { Block upward, buffer } \\
\text { downward }\end{array}$ & $I_{7} J_{13}$ & 0.13 \\
\hline Cylinder right & $I_{7} J_{14}$ & 2.43 & Cylinder downward & $I_{7} J_{15}$ & 1.32 \\
\hline Grip loosened & $I_{7} J_{16}$ & 0.32 & Cylinder upward & $I_{7} J_{17}$ & 1.43 \\
\hline Cylinder on the left & $I_{7} J_{18}$ & 2.65 & & & \\
\hline
\end{tabular}

Table 3.The optimal tact table of LED bulb production line based on CE-PSO algorithm.

\begin{tabular}{|c|c|c|c|c|c|c|c|c|c|c|c|}
\hline Workstage & \multicolumn{2}{|c|}{ Station 1} & \multicolumn{2}{|c|}{ Station 2} & \multicolumn{2}{|c|}{ Station 3} & Station 4 & Station 5 & Station 6 & \multicolumn{2}{|c|}{ Station 7} \\
\hline 1 & \multicolumn{2}{|c|}{0.13} & \multicolumn{2}{|c|}{0.13} & \multicolumn{2}{|c|}{0.13} & 0.13 & 0.13 & 0.13 & \multicolumn{2}{|c|}{0.13} \\
\hline 2 & 0.43 & 2.12 & 1.43 & 0.32 & 1.41 & 0.32 & 0.44 & 0.23 & \begin{tabular}{|l|l|}
1.37 & 0.32 \\
\end{tabular} & 0.43 & 1.83 \\
\hline 3 & $0.04 \mathrm{C}$ & \begin{tabular}{|l|l|}
0.44 & 0.15 \\
\end{tabular} & 0.51 & 0.04 & 0.53 & 0.04 & 0.04 & 0.04 & \begin{tabular}{|l|l|}
0.82 & 0.04 \\
\end{tabular} & 0.04 & 0.92 \\
\hline 4 & 0.12 & 0.05 & 0.76 & 0.12 & 0.51 & 0.12 & 0.12 & 0.12 & \begin{tabular}{|l|l|}
0.23 & 0.12 \\
\end{tabular} & 0.12 & 0.52 \\
\hline 5 & 0.04( & \begin{tabular}{l|l|}
0.44 & 0.15 \\
\end{tabular} & 0.34 & 0.04 & 0.44 & 0.04 & 0.04 & 0.04 & \begin{tabular}{|l|l|}
0.67 & 0.04 \\
\end{tabular} & 0.04 & 0.33 \\
\hline 6 & \multicolumn{2}{|c|}{2.48} & \multicolumn{2}{|c|}{1.98} & \multicolumn{2}{|c|}{1.94} & 0.45 & 4.37 & 1.82 & \multicolumn{2}{|c|}{1.55} \\
\hline 7 & \multicolumn{2}{|r|}{0.54} & \multicolumn{2}{|c|}{0.78} & \multicolumn{2}{|c|}{0.68} & 4.78 & \begin{tabular}{|l|l|}
0.32 & 0.41 \\
\end{tabular} & 1.07 & \multicolumn{2}{|c|}{0.43} \\
\hline 8 & \multicolumn{2}{|r|}{0.11} & \multicolumn{2}{|c|}{0.21} & \multicolumn{2}{|c|}{0.41} & \begin{tabular}{|l|l|}
0.13 & 0.12 \\
\end{tabular} & \begin{tabular}{|l|l|}
0.04 & 0.33 \\
\end{tabular} & 0.31 & 0.13 & 0.12 \\
\hline 9 & 0.13 & \begin{tabular}{|l|l|}
3 & 0.12 \\
\end{tabular} & 0.13 & 0.12 & 0.13 & 0.12 & 0.34 & \begin{tabular}{|l|l|}
0.13 & 0.45 \\
\end{tabular} & 0.13 & \multicolumn{2}{|c|}{\begin{tabular}{|l|}
0.32 \\
\end{tabular}} \\
\hline 10 & \multicolumn{2}{|c|}{0.32} & \multicolumn{2}{|c|}{0.3} & \multicolumn{2}{|c|}{0.4} & 0.04 & 0.13 & \begin{tabular}{|l|l|}
0.12 & 0.23 \\
\end{tabular} & 0.13 & 0.12 \\
\hline 11 & \multicolumn{2}{|r|}{0.04} & \multicolumn{2}{|c|}{0.04} & \multicolumn{2}{|c|}{0.04} & 0.13 & 0.34 & 0.04 & & 43 \\
\hline 12 & & 0.13 & & 13 & 0. & 13 & & 0.04 & 0.13 & & .04 \\
\hline 13 & & & & & & & & 0.13 & & & 13 \\
\hline Tact & & 6.93 & 6. & 74 & 6. & 75 & 6.64 & 6.76 & 6.95 & & 88 \\
\hline
\end{tabular}




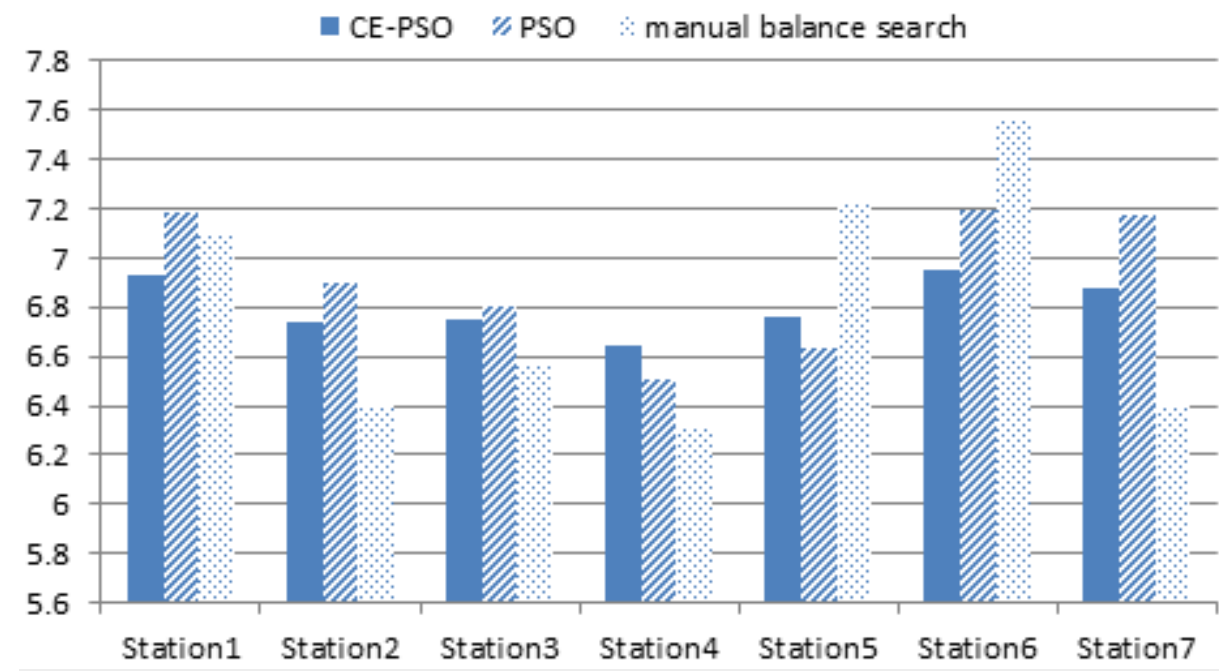

Figure 4. Tact optimization comparison of LED bulb production line

It can be seen that the smoothness of the optimization results of CE-PSO algorithm is better than other algorithms and the tact gap between stations is smallest, the waiting time between each station is shortest and the balancing rate of production line is the largest.

\section{Conclusion}

The tact optimization problem of LED bulb production line is a key question in the field of LED bulb production line design and management. The CE-PSO algorithm is adopted to solve the tact optimization problem with optimization goals tact and smoothness index. Compared with PSO algorithm and manual balance search algorithm, the simulation results show that the CE-PSO algorithm can minimize production tact and get highest production efficiency, production line balancing rate and smallest discrete conditions, which proves that the CE-PSO algorithm has more advantages in executing a global search and solve the production line tact optimization model.

\section{Acknowledge}

This project is supported by Shanghai Grand Science and Technology Program of China (Grant No. 16111105900) and Shanghai Municipal Commission of Economy and Informatization (Grant No. 160646)

\section{References}

1. Duanmu,Jun,Taaffe, Kevin, Production capabitlities using takt times, requirements analysis and simulation[J]. International Journalof Industrial and System Engineering, 10No.2,pp.197-216.( 2012)

2. Shan Dongri, Zhang Yanyan, Men Xiuhua, Optimization of production takt for automatic press line based onsynchronous motion of press and robot[J]. Applied Mechanics and Material,475No.8, pp:685-688(2013)

3. Xiaomei Hu, Yangyang Zhang, Zeng Ning, Wang Dong, A novel assembly line balancing method based on PSO algorithm. Mathematical Problems In Engineering,129No.2, pp: 242-250( 2014)

4. Gaing Z L. A particle swarm optimization approach for optimum design of PID controller in AVR system[J]. Energy Conversion, IEEE Transactions on, 19(2): 384-391( 2004)

5. Hall D L, McMullen S A H. Mathematical techniques in multisensor data fusion[M]. Artech House (2004) 